\title{
Expression cloning of a cDNA for the major Fanconi anaemia gene, FAA
}

J R L T Foe, M A Rooimans, L Bosnoyan-Collins, N Alon, M Wijker, L Parker, J Lightfoot, M Carreau, D F Callen, A Savoia, N C Cheng, C G M van Berkel, M H P Strunk, J J P Gille, G Pals, F A E Kruyt, J C Pronk, F Arwert, M Buchwald \& H Joenje

Nature Genetics 14, 320-323 (1996).

The nucleotide sequence used in Fig. 3 was inadvertantly cropped, resulting in improper alignment. The correct version is shown below.

Fig. 3 Nucleotide sequence of the FAA CDNA insert of the complementing clone D. An open reading frame starts at the first ATG (position 32) and ends at position 4399 with a TGA stop codon, predicting a protein of 1,455 amino acids. Amino acids are indicated by single letter codes. EMBL nucleotide sequence database accession number: X99226.

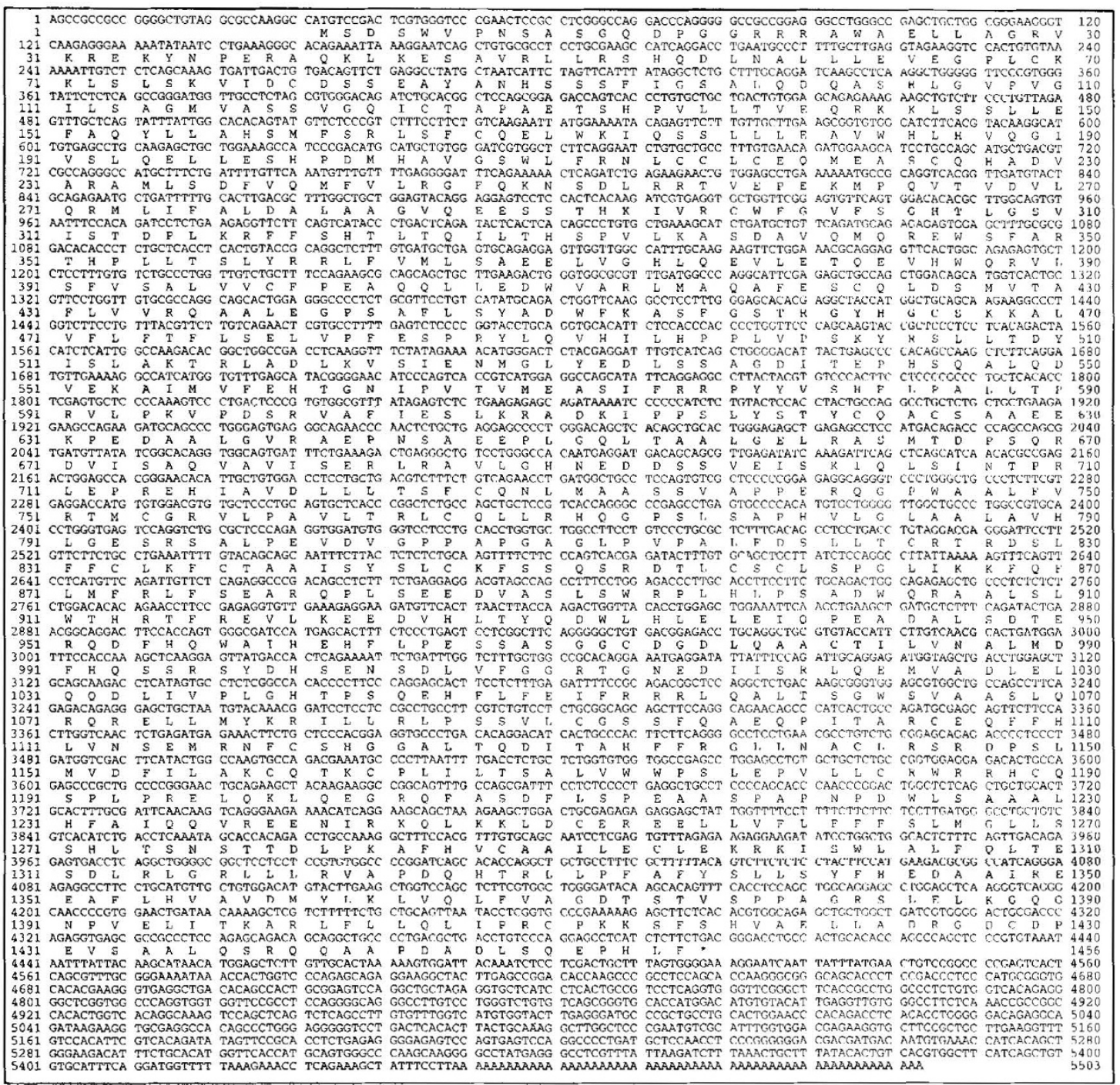

\section{The insulin-like growth factor II receptor gene is a target of microsatellite instability in human gastrointestinal tumours}

Nature Genetics 14, 255-257 (1996).

In this correspondence by Stephen J. Meltzer in the November issue, the name of co-author Haruhiko Sugimura was incorrectly listed as Hirohashi Sugimura. 